University of Montana

ScholarWorks at University of Montana

7-2009

\title{
Abundance and Density of Mountain Plover (Charadrius montanus) and Burrowing Owl (Athene cunicularia) in Eastern Colorado
}

\author{
Heather C. Tipton \\ Colorado State University - Fort Collins \\ Paul F. Doherty Jr. \\ Colorado State University - Fort Collins \\ Victoria J. Dreitz \\ University of Montana - Missoula, victoria.dreitz@cfc.umt.edu
}

Follow this and additional works at: https://scholarworks.umt.edu/wildbio_pubs

Part of the Life Sciences Commons

Let us know how access to this document benefits you.

\section{Recommended Citation}

Tipton, Heather C.; Doherty, Paul F. Jr.; and Dreitz, Victoria J., "Abundance and Density of Mountain Plover (Charadrius montanus) and Burrowing Owl (Athene cunicularia) in Eastern Colorado" (2009). Wildlife Biology Faculty Publications. 52.

https://scholarworks.umt.edu/wildbio_pubs/52

This Article is brought to you for free and open access by the Wildlife Biology at ScholarWorks at University of Montana. It has been accepted for inclusion in Wildlife Biology Faculty Publications by an authorized administrator of ScholarWorks at University of Montana. For more information, please contact scholarworks@mso.umt.edu. 


\begin{abstract}
Abundance and Density of Mountain Plover ( Charadrius montanus) and Burrowing Owl ( Athene cunicularia) in Eastern Colorado (Abundancia y Densidad de Charadrius montanus y Athene cunicularia en el Este de Colorado)
\end{abstract}

Author(s): Heather C. Tipton, Paul F. Doherty, Jr. and Victoria J. Dreitz

Source: The Auk, Vol. 126, No. 3 (July 2009), pp. 493-499

Published by: University of California Press on behalf of the American Ornithologists' Union

Stable URL: http://www.jstor.org/stable/10.1525/auk.2009.07172

Accessed: 20/11/2013 11:56

Your use of the JSTOR archive indicates your acceptance of the Terms \& Conditions of Use, available at

http://www.jstor.org/page/info/about/policies/terms.jsp

JSTOR is a not-for-profit service that helps scholars, researchers, and students discover, use, and build upon a wide range of content in a trusted digital archive. We use information technology and tools to increase productivity and facilitate new forms of scholarship. For more information about JSTOR, please contact support@jstor.org. 


\title{
ABUNDANCE AND DENSITY OF MOUNTAIN PLOVER (CHARADRIUS MONTANUS) AND BURROWING OWL (ATHENE CUNICULARIA) IN EASTERN COLORADO
}

\author{
Heather C. Tipton, ${ }^{1,3}$ Paul F. Doherty, Jr., ${ }^{1}$ and Victoria J. Dreitz ${ }^{2}$ \\ ${ }^{1}$ Department of Fish, Wildlife, and Conservation Biology, 1474 Campus Delivery, Colorado State University, Fort Collins, Colorado 80523, USA; and \\ ${ }^{2}$ Colorado Division of Wildlife, 317 West Prospect Road, Fort Collins, Colorado 80526, USA
}

\begin{abstract}
Because of continental-scale declines of grassland birds over the past century, conservation agendas are focused on increasing understanding of grassland bird ecology and habitat associations. Shortgrass prairie is a unique grassland ecosystem maintained, in part, by Black-tailed Prairie Dogs (Cynomys ludovicianus). The Mountain Plover (Charadrius montanus) and western Burrowing Owl (Athene cunicularia hypugaea) are species of conservation concern known to be associated with prairie dog colonies. We estimated abundance of Mountain Plovers and Burrowing Owls in three habitats within the Colorado shortgrass prairie ecosystemprairie dog colonies, grassland not occupied by prairie dogs, and dryland agriculture. Further, we investigated habitat associations of Mountain Plovers and Burrowing Owls at multiple landscape scales. We estimated 8,577 Mountain Plovers (95\% CI: 7,511-35,130) and 3,554 Burrowing Owls (95\% CI: 3,298-8,445) in eastern Colorado. Mountain Plover density on prairie dog colony plots $(\hat{D}=2.26$ birds per 100 ha, 95\% CI: 2.15-5.13) was significantly higher than densities on either grassland ( $\hat{D}=0.23$, 95\% CI: 0.17-1.76) or drylandagriculture plots $(\hat{D}=0.45,95 \%$ CI: $0.44-0.53)$. Burrowing Owl density on prairie dog colony plots $(\hat{D}=3.04$ birds per 100 ha, $95 \%$ CI: 2.82-6.92) was significantly higher than densities on either grassland ( $\hat{D}=0.044,95 \%$ CI: $0.041-0.12)$ or dryland-agriculture plots (no Burrowing Owls detected). Our results suggest that increased prairie dog colonies would positively influence the abundance of Mountain Plover and Burrowing Owl. Received 14 October 2007, accepted 9 January 2009.
\end{abstract}

Key words: abundance, Athene cunicularia, Burrowing Owl, Charadrius montanus, double-observer methods, Mountain Plover, shortgrass prairie.

\section{Abundancia y Densidad de Charadrius montanus y Athene cunicularia en el Este de Colorado}

RESUMEN.-Debido a las disminuciones de las poblaciones de aves de pastizales a escala continental sucedidas durante el último siglo, las agendas de conservación están enfocadas en aumentar el conocimiento de la ecología y las asociaciones de hábitat de las aves de estos ambientes. Las praderas de pastos cortos son ecosistemas únicos que son mantenidos parcialmente por los perros de la pradera (Cynomys ludovicianus). Charadrius montanus y Athene cunicularia hypugaea son aves de interés en conservación que se encuentran asociadas con las colonias de C. ludovicianus. Estimamos la abundancia de C. montanus y A. cunicularia en tres hábitats en el ecosistema de praderas de pastos cortos de Colorado: colonias de C. ludovicianus, pastizales no ocupados por C. ludovicianus y áreas agrícolas secas. Además, investigamos las asociaciones de C. montanus y A. cunicularia a varias escalas de paisaje. Estimamos que existen 8,577 individuos de C. montanus (IC del 95\%: 7,511-35,130) y 3,554 de A. cunicularia (IC del 95\%: 3,298-8,445) en el este de Colorado. La densidad de C. montanus en las parcelas ubicadas en colonias de C. ludovicianus ( $\hat{D}=2.26$ aves por 100 ha, IC del $95 \%$ : 2.15-5.13) fue significativamente más alta que en las ubicadas en pastizales ( $\hat{D}=0.23$, IC del 95\%: 0.17-1.76) y en áreas agrícolas secas $(\hat{D}=0.45$, IC del 95\%: 0.44-0.53). La densidad de A. cunicularia en las colonias de C. ludovicianus $(\hat{D}=3.04$ aves por 100 ha, IC del 95\%: 2.82-6.92) fue significativamente mayor que en los pastizales ( $\hat{D}=0.044$, IC del 95\%: 0.041-0.12) y en las áreas agrícolas (ningún individuo fue detectado). Nuestros resultados sugieren que un incremento en las colonias de C. ludovicianus afectaría positivamente la abundancia de C. montanus y A. cunicularia.

NATIVE GRASSLANDS HAVE been altered to a greater extent than any other biome in North America (Samson et al. 2004), resulting in the conversion of a once diverse grassland landscape into a collection of homogeneous grassland fragments interspersed with agricultural fields (Smith and Lomolino 2004). These alterations have likely resulted in continental-scale declines in grassland avifaunas (Knopf 1994, 1996). Historically, the shortgrass prairie was maintained by native grazers, primarily American Bison (Bison

${ }^{3}$ Present address: U.S. Fish and Wildlife Service, 1339 20th Street, Vero Beach, Florida 32960, USA. E-mail: heather_tipton@fws.gov

The Auk, Vol. 126, Number 3, pages 493-499. ISSN 0004-8038, electronic ISSN 1938-4254. ( 2009 by The American Ornithologists' Union. All rights reserved. Please direct all requests for permission to photocopy or reproduce article content through the University of California Press's Rights and Permissions website, http://www.ucpressjournals. com/reprintInfo.asp. DOI: 10.1525/auk.2009.07172 
bison) and prairie dogs (Cynomys spp.; Knopf 1994, 1996). Today, the ecological functioning of shortgrass prairie relies heavily on the disturbance caused by its remaining native grazer, the Black-tailed Prairie Dog (C. ludovicianus; hereafter "prairie dog"), and drought conditions (Askins et al. 2007). In addition, cattle grazing functions as a secondary ecological driver (Milchunas et al. 1990, Milchunas and Lauenroth 1993, Samson and Knopf 1996; but see Schlesinger et al. 1990, Brown and McDonald 1995). Although prairie dogs covered $\geq 40$ million ha in the early 20 th century, eradication efforts, sylvatic plague (Yersinia pestis), and habitat destruction and fragmentation have reduced their coverage to $<5 \%$ of that area today (Miller et al. 1994, Smith and Lomolino 2004).

Of the numerous grassland species closely associated with prairie dog colonies, many have declined and are species of concern (Smith and Lomolino 2004, and references therein), including Mountain Plover (Charadrius montanus) and western Burrowing Owl (Athene cunicularia hypugaea). Conservation efforts to reverse avian population declines require reliable information on population status and habitat requirements. Thus, it is important that the methodologies used to estimate population parameters address two important considerations: a probability-based sampling frame and incorporation of detection probability into population estimates (Williams et al. 2002). We incorporated a probability-based sampling approach to widen inference to include habitats within the shortgrass prairie of Colorado and to avoid potential bias associated with convenience or road-based sampling. We employed the dependent double-observer approach (Nichols et al. 2000), an observationbased mark-recapture method, to estimate the breedingground abundance of Mountain Plover and Burrowing Owl within the shortgrass prairie ecosystem of Colorado. We focused on Mountain Plover and Burrowing Owl because of their conservation status.

In Colorado, Mountain Plovers use habitats within the shortgrass prairie, including agricultural fields and prairie dog colonies, for breeding activity (Knopf and Rupert 1999, Dreitz et al. 2005). In other grassland systems, specifically in Montana, Mountain Plovers are strongly associated with prairie dog colonies (Knowles et al. 1982, Dinsmore et al. 2005). The nature of this relationship in Colorado is not well understood (Dreitz et al. 2005, Knopf and Wunder 2006). Burrowing Owls also are highly associated with prairie dog colonies in shortgrass prairie (Barko et al. 1999, VerCauteren et al. 2001, Smith and Lomolino 2004), and the relative use of prairie dog colonies by Burrowing Owls may be directly related to colony activity status (Dechant et al. 2003, and references therein). We tested predictions concerning differences in plot-level abundance and detection of Mountain Plovers and Burrowing Owls across three habitats within the shortgrass prairie-prairie dog colonies, native grassland not occupied by prairie dogs (hereafter "grassland"), and dryland agriculture-as well as predictions concerning the influence of surrounding habitat at multiple spatial scales. We predicted that abundance of the two species would be highest on prairie dog colony plots, and positively associated with the presence of active prairie dogs and the relative area of prairie dog colonies in the landscape.

\section{Methods}

Study area.-The study area was located on private and public lands in eastern Colorado, $\sim 48 \mathrm{~km}$ east of Interstate 25 (to avoid urban and exurban areas), and encompassed $\sim 81,200 \mathrm{~km}^{2}$ in 20 counties. We determined that $\sim 72.8 \%$ of the study area was shortgrass prairie (48.8\% grassland, $21.7 \%$ dryland agriculture, and $2.3 \%$ prairie dog colonies). The remaining $27.2 \%$ was native shrubland, wetland, riparian, irrigated agriculture, or Conservation Reserve Program land (for a discussion of the land-cover data we used, see Tipton 2007). Prairie dog colonies and grassland were dominated by low-growing perennial grasses such as Buffalograss (Buchloe dactyloides) and Blue Grama (Bouteloua gracilis) exposed to varying cattle-grazing regimes. "Dryland agriculture" comprised fallow fields and unirrigated crops such as wheat and millet.

Sample-plot selection.-We selected sample plots within our three habitats using equal sample allocation within a spatially balanced sampling design (Stevens and Olsen 2004, Theobald et al. 2007) applied in ARCGIS, version 9.0 (ESRI, Redlands, California). Sample plots were $500 \times 500 \mathrm{~m}(25 \mathrm{ha})$, categorized as prairie dog colony, grassland, or dryland agriculture. We based plot size on the minimum estimated brood-rearing territory of Mountain Plovers (28 ha; Knopf and Rupert 1996), which is considerably larger than that of Burrowing Owls (4-6 ha; Grant 1965).

Once sampling plots were selected, we made contacts to gain access to private land. We based final plot selection on qualitative habitat assessments, using the following criteria: (1) prairie dog colony plots had $\geq 25 \%$ coverage by active or inactive prairie dog colonies, and (2) grassland and dryland-agriculture plots had $100 \%$ coverage of the respective cover type. Plots that did not meet these criteria were excluded from the sampling frame. We classified the activity status of prairie dog colonies on the basis of site observations of prairie dogs or prairie dog sign (e.g., fresh scat). Plots with inactive colonies (i.e., no evidence of prairie dogs) were surveyed only if above-ground conditions were not visibly different from those of active colonies (e.g., short vegetation, moderate amounts of bare ground, and relatively intact, clean burrows). Plot boundaries could go up to, but not overlap, major roads to allow for safety considerations.

Field-data collection.-We conducted double-observer surveys from 19 May to 6 June 2005, following protocol described by Nichols et al. (2000). Surveying during this period facilitated detection of adults while still allowing observers to differentiate between young and adult birds. We conducted a single survey of each plot during either the morning (between sunrise and 1000 hours MST) or evening (between 1730 hours and sunset) and only under acceptable weather conditions (temperatures $\leq 27^{\circ} \mathrm{C}$, wind speeds $\leq 6.0 \mathrm{~m} \mathrm{~s}^{-1}$, visibility to $\geq 125 \mathrm{~m}$ ). At the beginning and end of each survey, we recorded time and weather conditions with a digital temperature and wind meter.

We began surveys at the southeast corner of each plot. Observers conducted a walking transect that passed within $125 \mathrm{~m}$ of all parts of the study plot (Fig. 1). The 125-m limit was based on evidence of decreased detection of Mountain Plovers at distances $\geq 125 \mathrm{~m}$ (Wunder et al. 2003). Surveys were conducted by five teams of two observers each, one designated as the "primary" observer and the other as the "secondary" observer. Walking transects single-file, the primary observer identified all adults 


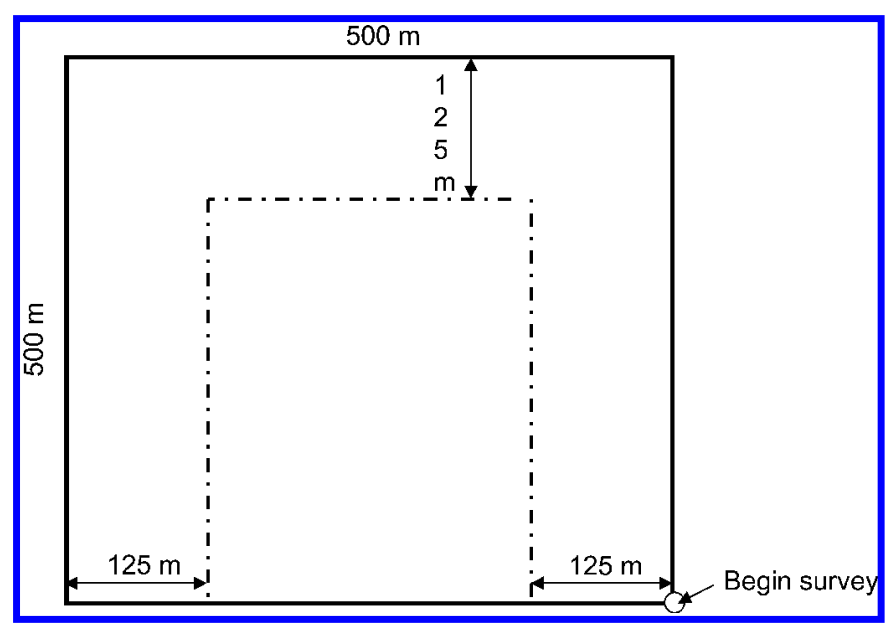

FIG. 1. Diagram of transect walked by observers during double-observer surveys conducted on randomly selected $500 \times 500 \mathrm{~m}$ plots in eastern Colorado in 2005

seen or heard within the plot and communicated each individual detection, detection type, and approximate location to the secondary observer, who recorded the information. The secondary observer also surveyed the plot and recorded any additional individuals. Observer roles were alternated on consecutive surveys We employed various techniques, including maintaining a minimum distance and faking observations, to prevent the secondary observer from cueing the primary observer to an individual. We recorded auditory-only observations ( $7 \%$ of observations) when an individual bird was thought to be within plot boundaries. Surveys lasted 30-65 min.

Statistical analysis.-We estimated plot-level detection probabilities $(p)$ and abundances $(N)$ using the Huggins closedcaptures model (Huggins 1989, 1991) in program MARK (White and Burnham 1999). This model allows modeling of $p$ with individual covariates (discussed below). Before building our models, we examined the available variance and correlation for all our measured covariates. If there was no variability in a covariate, it would not be useful in modeling exercises. If covariates were highly correlated $(R \geq 0.50)$, we excluded one of the correlated variables to keep our set of variables as independent as possible (Tipton 2007), with the recognition that correlation does not imply causation, because there could be many correlated variables that we did not measure that influenced the results. Our highly correlated covariates were those representing the average and maximum values of our survey weather covariates (i.e., temperature and wind); we chose to use the average values and exclude maximum values. Probability of recapture $(c)$ was set to zero for all models to simulate a removal model based on dependent double-observer methodology.

We used Akaike's information criterion corrected for small sample size ( $\mathrm{AIC}_{\mathrm{c}}$ ) to rank models (Burnham and Anderson 2002). We calculated habitat-specific densities using the derived abundance estimates generated under the highest-ranking $\left(\Delta \mathrm{AIC}_{\mathrm{c}}=0\right)$ model for each species. We extrapolated our calculated density estimates to an area that accounts for nonresponse problems (e.g. habitat misclassification, logistical issues, denial of access) to obtain Mountain Plover and Burrowing Owl population estimates
(Tipton 2007). For example, of the grassland plots selected for sampling, we were unable to reach landowners for $\sim 45 \%$ of plots and were denied access for another $15 \%$. Thus, a statistically valid extrapolation is limited to $\sim 40 \%$ of grassland habitat in our study area.

Because the abundance parameter $(N)$ is not included in the formal likelihood in the Huggins model (Huggins 1989, 1991), but is a derived parameter, effects of habitat factors (see below) on abundance cannot be compared using the $\mathrm{AIC}_{\mathrm{c}}$ model-selection framework. Instead, we used variance components analysis (also available in MARK) to examine the amount of process variance (sensu Link and Nichols 1994) in abundance explained by each habitat covariate. Overall variance in abundance among plots has two components: sampling variance and process variance. Sampling variance is nuisance variance attributable to the sampling methods. Process variance is the biological variance and is the component we are interested in explaining. We were able to calculate the amount of process variation in abundance explained by each covariate, as well as the residual variation.

Covariates affecting detection.-We modeled $p$ as either constant or a function of selected visit-specific covariates including day (a model with general temporal variance), average temperature (warmer temperatures might make birds less active), and average wind speed (higher wind speeds might make birds more difficult to detect). Because observers vary in their ability and experience, we included a model in which observer team would affect $p$. Observer team 1 included a field-crew member who had substantially less experience than the other crew members, and we predicted that team 1 would have a lower $p$ value for both species. The above variables were included individually or in additive combinations. Although plot habitat likely influenced $p$, low numbers of detections of both species on grassland or agricultural plots prevented the inclusion of plot habitat as a factor affecting $p$.

Covariates affecting abundance.-To investigate specieshabitat associations, we tested the effect of plot-level and landscape-level habitat characteristics on Mountain Plover and Burrowing Owl abundance. Because of the high correlation of nested variables, we selected three plot-level and six landscapelevel covariates. Plot-level habitat covariates included habitat type and, for prairie dog colony plots, colony activity status and the area of prairie dog colonies within plot boundaries (required to be $\geq 25 \%$ of total area). For our landscape-level habitat covariates, we were interested in the effect of varying amounts of prairie dog colony and grassland surrounding the plot at three landscape-level scales: plot plus 500-m, 1,500-m, or 2,250-m buffer (Tipton 2007). We used digital aerial photographs taken during the field season to identify prairie dog colonies within 2,250 $\mathrm{m}$ of surveyed plot boundaries (Tipton 2007). We digitized these data and combined the resulting prairie dog colony layer with existing land-cover data to obtain plot- and landscape-level habitat variables representing the percent cover of prairie dog colony and grassland.

For Mountain Plover, we predicted abundance on prairie dog colony plots $>$ dryland agriculture plots $>$ grassland plots. For Burrowing Owl, we predicted that abundance would be highest on prairie dog colony plots, with very few Burrowing Owls expected on grassland and dryland-agriculture plots. For both species, we predicted that the presence of prairie dogs would have a strong positive effect on species abundance. 
Landscapes containing more native grassland may represent higher-quality breeding habitat (Hamer et al. 2006). Thus, we predicted a positive relationship between grassland landscape variables and species abundance. We also predicted a positive effect of increasing amounts of prairie dog colony in the landscape (at all spatial scales) on species abundance. This hypothesis was based on species' breeding ecologies and habitat preferences, including association with prairie dog complexes (Dechant et al. 2003, and references therein; Dreitz et al. 2005).

\section{RESULtS}

We surveyed a total of 272 plots: 84 in prairie dog colonies, 98 in grassland, and 90 in dryland agriculture. Approximately $92 \%$ of surveyed plots were located on private land. Fifty-nine Mountain Plovers were detected on 31 of the surveyed plots, and 60 Burrowing Owls were detected on 35 of the surveyed plots. Forty-five Mountain Plovers were detected on 21 prairie dog colony plots, 4 were detected on 3 grassland plots, and 10 were detected on 7 dryland-agriculture plots. Burrowing Owls were detected mainly on prairie dog colony plots (59 detections on 34 plots); one was detected on grassland, and none on dryland-agriculture plots.

Mountain Plover.-Models in which $p$ was modeled as a function of observer team (obs1 $\neq$ obs $2-5$ ) consistently ranked higher than models in which $p$ was modeled as constant (.) or allowed to vary by other covariates (day, temperature, and wind). There was some evidence of a negative effect of the variable obs1 on detection, as predicted ( $\hat{\beta}=-3.91,95 \%$ confidence interval [CI]: -9.48 to 1.65$)$. Average detection probability, as estimated under the model with constant $p$, was 0.93 (95\% CI: 0.81-0.97). On occupied plots, the estimated number of Mountain Plovers ranged from one to four individuals per plot. Mountain Plover density on prairie dog colony plots $(\hat{D}=2.26$ birds per 100 ha, 95\% CI: 2.15-5.13) was significantly higher than densities on either grassland ( $\hat{D}=0.23,95 \%$ CI: $0.17-1.76)$ or dryland-agriculture plots ( $\hat{D}=0.45,95 \%$ CI: 0.44-0.53; Fig. 2). Extrapolation of these densities indicates a Mountain Plover population of 8,577 (95\% CI: 7,511-35,130).

Results of variance component analysis suggest that the amount of prairie dog colony within $500 \mathrm{~m}$ of the plot explained the most process variance in Mountain Plover abundance estimates (11.32\% of variance explained). The amount of prairie dog colony within the plot and within $1,500 \mathrm{~m}$ and $2,250 \mathrm{~m}$ also explained some process variance $(6.60 \%, 8.49 \%$, and $2.83 \%$, respectively). Although plot habitat and prairie dog activity status each explained $4.72 \%$ of the process variance, the amount of grassland in the landscape at any scale explained very little, if any, of the process variance.

Burrowing Owl.-Because of the low numbers of detections by two of the observer teams, models in which $p$ varied by observer team were not possible. The model in which $p$ was kept constant ranked higher than models in which $p$ was allowed to vary by our covariates. Under this model, $p=0.72$ (95\% CI: $0.53-0.86$ ). On occupied plots, the estimated number of Burrowing Owls ranged from one to six individuals per plot. Results of variance component analysis suggest that none of the measured covariates explained underlying process variance in Burrowing Owl abundance estimates. Burrowing Owl density on prairie dog colony plots

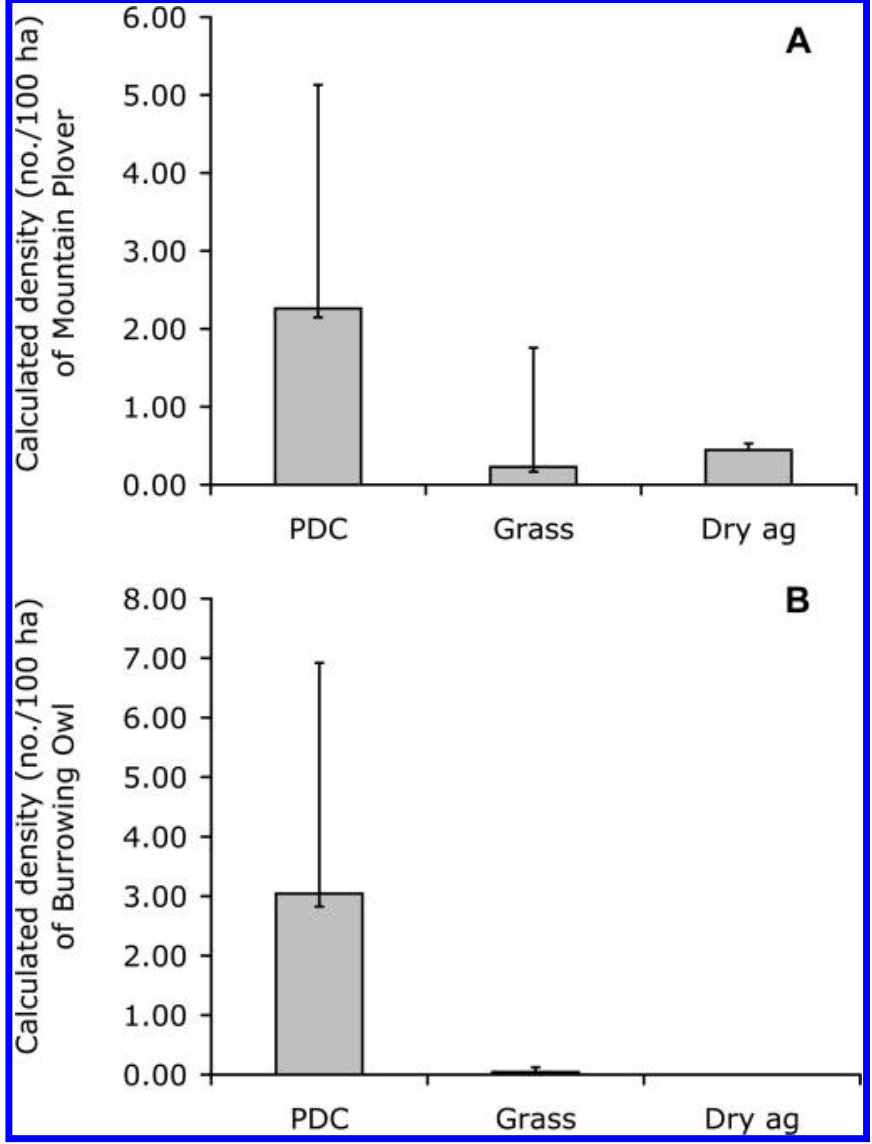

FIG. 2. Calculated density of (A) Mountain Plover and (B) Burrowing Owl in three habitats - prairie dog colony (PDC), grassland (Grass), and dryland agriculture (Dry ag) —within the Colorado shortgrass prairie ecosystem in 2005. No Burrowing Owls were detected on the 91 drylandagriculture plots surveyed in 2005. Densities were calculated from derived abundance estimates generated under the highest-ranking model for detection probability for each species. Error bars represent 95\% confidence intervals.

( $\hat{D}=3.04$ birds per 100 ha, $95 \%$ CI: $2.82-6.92)$ was significantly higher than densities on either grassland $(\hat{D}=0.044,95 \% \mathrm{CI}$ : 0.041-0.12) or dryland-agriculture plots (no owls detected; Fig. 2). Extrapolation of these densities indicates a Burrowing Owl population of 3,554 (95\% CI: 3,298-8,445).

\section{Discussion}

The historical factors that shaped the shortgrass prairie of North America produced an ecosystem characterized by local homogeneity and regional heterogeneity (Samson et al. 2004, Askins et al. 2007). Avian diversity evolved with this heterogeneity, and prairie dogs were a major factor shaping the local homogeneity of this ecosystem (Miller et al. 1994, Smith and Lomolino 2004). Various species depend on these local homogenized patches, and our results suggest that Mountain Plover and Burrowing Owl, at least, are present in greater numbers on prairie dog habitat than on grassland or dryland agricultural habitat. 
Effects on abundance.-For both Mountain Plover and Burrowing Owl, mean abundance was higher on prairie dog colony plots than on grassland or dryland-agriculture plots. This is similar to the results of Winter et al. (2003), which indicated positive associations with prairie dog colonies in southeastern Colorado and southwestern Kansas. Smith and Lomolino (2004) also observed a positive association between prairie dog habitat and Burrowing Owls in the Oklahoma panhandle.

Mountain Plover abundance on occupied plots showed a positive relationship with the amount of prairie dog colony in the landscape. The amount of prairie dog colony in the landscape at $500 \mathrm{~m}$ explained most of the process variation (11.32\%) in Mountain Plover abundance. This landscape encompasses an average broodrearing territory (Knopf and Rupert 1996, Dreitz et al. 2005). By contrast, our landscape variables failed to explain any process variance in abundance estimates of Burrowing Owl. These results contrast with those of Orth and Kennedy (2001) in northeastern Colorado, which suggested that the percentage of an area covered by grassland was an important predictor.

Activity status of prairie dog colony plots explained some process variance in Mountain Plover abundance but did not explain process variance in Burrowing Owl abundance. This result, as well as the failure of our other habitat variables to explain process variance in Burrowing Owl abundance, is likely related to the small amount of variance in Burrowing Owl abundance to be explained: of the 35 plots that had Burrowing Owls, 91.4\% had one or two individuals, and the same proportion had active prairie dogs. For the Mountain Plover, the lack of explanatory power of measured habitat covariates suggests that other factors cause between-plot variation in abundance. These factors may include smaller, patchor plot-level variables such as vegetation characteristics, microclimates, and prey availability. In addition, habitat fragmentation (which can be expressed in measures of patch size and shape) and habitat degradation may also limit abundance. Thus, measures of habitat quality, structure, and configuration may also be necessary to describe variation in estimated abundance of Mountain Plover and Burrowing Owl.

Abundance and density estimation.-Statistically reliable population estimates did not exist, before the present study, for either study species within the shortgrass prairie of eastern Colorado. Our extrapolated abundance estimate of 8,577 breeding Mountain Plovers does not include an isolated breeding population of 2,310 breeding adults in South Park, Park County, Colorado (Wunder et al. 2003). These two estimates combined suggest that $>10,000$ Mountain Plovers breed in Colorado-a large portion of the estimated global population of 11,000-14,000 (Plumb et al 2005). However, we believe that the global population estimate needs to be revised to $15,000-20,000$ individuals. Our extrapolated estimate of 3,554 Burrowing Owls is lower than previous reports of 15,796 in eastern Colorado (Hanni 2002). Obtaining abundance estimates for Burrowing Owls presents an additional challenge, in that one or both members of a pair could be in a burrow, and unavailable for detection, during site visits. This would result in an estimate of the "available" population, but an underestimate of the total population.

Estimated densities of Mountain Plovers and Burrowing Owls in our study area were lower than estimates from other portions of their ranges. On surveyed prairie dog colony plots, we calculated
Mountain Plover density as 2.26 birds per 100 ha, with an average density of 0.93 birds per 100 ha on surveyed plots across all three habitats. This is much lower than the average density of 7.9 birds per 100 ha reported by Wunder et al. (2003) from South Park and the 2.0-4.7 birds per 100 ha reported from the Pawnee National Grassland in northeastern Colorado (1990-1994; Knopf and Wunder 2006). Similar densities have been observed on prairie dog colonies in Montana (1.28-6.80 birds per 100 ha, 1991-1995; Knopf and Wunder 2006), appearing to vary with seasonal climatic conditions. Higher densities have been found on known breeding locales in Wyoming (average 4.47 birds per 100 ha; Plumb et al. 2005). Of these estimates, only those from South Park and Wyoming were adjusted for detection error.

Our calculated density estimates for Burrowing Owl were equally low (3.04 birds per $100 \mathrm{ha}$ ) on surveyed prairie dog colony plots, with an average density of 0.96 birds per 100 ha on surveyed plots across all three habitats. Hughes (1993) reported densities of $2-1,450$ owls per 100 ha on prairie dog colonies in northeastern Colorado, though counts were not adjusted for detection error. Desmond and Savidge (1996) found 10-3,000 owls per 100 ha on prairie dog colonies in the Nebraska panhandle using counts not adjusted for detection error, with density varying by colony size. Conway and Simon (2003) estimated Burrowing Owl density as 0.15-0.22 birds per 100 ha in Wyoming using counts adjusted for detection, but inference is limited to roadside habitat.

Differences between our results and previous density estimates may be attributable to the sampling frame used. Whereas most previous surveys were conducted only in known occupied areas and areas of higher concentrations, our study employed a probability-based sampling frame in which all areas meeting plot habitat criteria were open to sampling, including unoccupied areas and areas of low concentrations. This resulted in lower calculated densities than would have been obtained had we only surveyed areas where each species was known to occur in high numbers.

Limitations of inference.-Inference is limited by the short time-span of our study. A single-year study cannot consider the changing habitat conditions in eastern Colorado that result from fluctuations in precipitation and temperature. Therefore, replication and longer-term studies are desirable to obtain additional information on species-habitat associations through time.

Our results are limited to the entire eastern portion of Colorado by the proportion of plots that could not be included in our sampling frame because of nonresponse issues (described above). Because of this limited inference, our extrapolated population estimates should be considered conservative. In addition, our population estimates may be biased low because they did not include individuals using habitat types excluded from our study (e.g., irrigated agriculture, shrublands, plots with $<25 \%$ coverage by prairie dog colonies). We also note that our abundance estimates are habitat-specific and, thus, dependent on our estimates of habitat coverage within the study area. If different habitat information is used (e.g., different estimates of amount of prairie dog habitat or different GIS vegetation layers), the resulting abundance estimates may vary greatly from those presented here.

Our estimates of abundance and density may be biased low if birds were within the plot but unavailable for detection. Marsh and Sinclair (1989) and Diefenbach et al. (2007) made the distinction between two types of detection probabilities: (1) the probability 
that a bird is available to be detected; and (2) the probability tha $\rightarrow$ Conway, C. J., AND J. C. Simon. 2003. Comparison of detection a bird is detected, given that it is available for detection. Our detection probability estimated the latter. Although the probability that a bird is available to be detected is important to consider in estimating abundance, we believe that in open habitats, such as shortgrass prairie, most Mountain Plovers were available for detection. By contrast, some Burrowing Owls may have been underground in burrows and, thus, unavailable for detection, resulting in an underestimation of their numbers.

Monitoring, management, and conservation of grasslanc birds will remain topics of importance. Controversy surrounding the effects that prairie dogs have on the shortgrass ecosystem and its other inhabitants will likely continue. Conservation action: must include both targeted land-acquisition and partnerships with private landowners to meet land-management goals over a broad scale to achieve successful results. Additional research should be $\rightarrow$ conducted to refine our knowledge of species-habitat relationships in the shortgrass prairie and to investigate other potentially important habitat factors on avian population parameters. De spite these continued challenges, we believe that the results of the present study will serve to inform grassland bird-conservation issues and provide impetus for implementing more rigorous sampling and survey methodologies in broad-scale studies. probability associated with Burrowing Owl survey methods. Journal of Wildlife Management 67:501-511.

Dechant, J. A., M. L. Sondreal, D. H. Johnson, L. D. IgL, C. M. Goldade, P. A. Rabie, AND B. R. Euliss. 2003. Effects of management practices on grassland birds: Burrowing Owl. [Online.] Northern Prairie Wildlife Research Center, Jamestown, North Dakota. Available at www.npwrc.usgs.gov/resource/literatr/ grasbird/buow/buow.htm.

Desmond, M. J., And J. A. SAvidge. 1996. Factors influencing Burrowing Owl (Speotyto cunicularia) nest densities and numbers in western Nebraska. American Midland Naturalist 136:143-148.

Diefenbach, D. R., M. R. Marshall, J. A. Mattice, and D. W. BRAUNING. 2007. Incorporating availability for detection in estimates of bird abundance. Auk 124:96-106.

Dinsmore, S. J., G. C. White, And F. L. Knopf. 2005. Mountain Plover population responses to black-tailed prairie dogs in Montana. Journal of Wildlife Management 69:1546-1553.

Dreitz, V. J., M. B. Wunder, And F. L. Knopf. 2005. Movements and home ranges of Mountain Plovers raising broods in three Colorado landscapes. Wilson Bulletin 117:128-132.

Grant, R. A. 1965. The Burrowing Owl in Minnesota. Loon 37: $2-17$.

\section{ACKNOWLEDGMENTS}

We thank the hundreds of private landowners throughout eastern Colorado who allowed access to their lands. We also thank the Colorado Division of Wildlife, Colorado State University, and the Colorado Chapter of The Wildlife Society for financial support. The Division of Wildlife Area and Wildlife Managers, the Shortgrass Steppe Long-term Ecological Research Center, and the $\rightarrow$ U.S. Forest Service at the Pawnee and Comanche National Grasslands supplied additional logistic support. B. R. Noon and D. M Theobald assisted with study design. GIS data were provided by M. Hattis, J. Kindler, G. Mason, S. McClean, S. McFarland, M. Menefee, and D. M. Theobald. Field assistance was provided by L. Dennis, M. Gilbert, P. Hargis, J. Hoffman, Z. Holderby, L. Juliusson, T. Paul, M. Prasek, and J. Waite. E. Bergman, B. Walker, two anonymous reviewers, and D. H. Johnson provided helpful comments on earlier drafts of the manuscript.

\section{Literature Cited}

Askins, R. A., F. Chávez-Ramírez, B. C. Dale, C. A. Haas, J. R. Herkert, F. L. Knopf, And P. D. Vickery. 2007. Conservation of grassland birds in North America: Understandin ecological process in different regions. Ornithological Monographs, no. 64.

$\rightarrow$ Barko, V. A., J. H. Shaw, and D. M. Leslie, Jr. 1999. Birds associated with black-tailed prairie dog colonies in southern shortgrass prairie. Southwestern Naturalist 44:484-489.

$\rightarrow$ Brown, J. H., AND W. MCDonald. 1995. Livestock grazing and conservation on southwestern rangelands. Conservation Biology 9:1644-1647.

Burnham, K. P., And D. R. Anderson. 2002. Model Selection and Multimodel Inference: A Practical Information-theoretic Approach, 2nd ed. Springer-Verlag, New York.

$\rightarrow$ Hamer, T. L., C. H. Flather, and B. R. Noon. 2006. Factors associated with grassland bird species richness: The relative roles of grassland area, landscape structure, and prey. Landscape Ecology 21:569-583.

HanNI, D. 2002. A comparison of four methodologies used to monitor shortgrass prairie birds in eastern Colorado. Rocky Mountain Bird Observatory and Colorado Division of Wildlife, Fort Collins.

Huggins, R. M. 1989. On the statistical analysis of capture experiments. Biometrika 76:133-140.

$\rightarrow$ Huggins, R. M. 1991. Some practical aspects of a conditional likelihood approach to capture experiments. Biometrics 47:725-732.

Hughes, A. J. 1993. Breeding density and habitat preference of the Burrowing Owl in northeastern Colorado. M.S. thesis, Colorado State University, Fort Collins.

KNOPf, F. L. 1994. Avian assemblages on altered grasslands. Pages 247-257 in A Century of Avifaunal Change in Western North America (J. R. Jehl, Jr., and N. K. Johnson, Eds.). Studies in Avian Biology, no. 15.

KNOPF, F. L. 1996. Prairie legacies-birds. Pages 135-148 in Prairie Conservation: Preserving North America's Most Endangered Ecosystem (F. B. Samson and F. L. Knopf, Eds.). Island Press, Washington, D.C.

KNOpf, F. L., AND J. R. Rupert. 1996. Reproduction and movements of Mountain Plovers breeding in Colorado. Wilson Bulletin 108:28-35.

KNOPf, F. L., AND J. R. Rupert. 1999. The use of cultivated fields by breeding Mountain Plovers. Pages 81-86 in Ecology and Conservation of Grassland Birds of the Western Hemisphere (P. D. Vickery and J. R. Herkert, Eds.). Studies in Avian Biology, no. 19.

KNOPF, F. L., ANd M. B. Wunder. 2006. Mountain Plover (Charadrius montanus). In The Birds of North America Online. Cornell Laboratory of Ornithology, Ithaca, New York. [Online.] Available at bna.birds.cornell.edu/bna/species/211/articles/ introduction. 
$\rightarrow$ Knowles, C. J., C. J. Stoner, and S. P. Gieb. 1982. Selective ust $\rightarrow$ Schlesinger, W. H., J. F. Reynolds, G. L. Cunningham, L. F. of black-tailed prairie dog towns by Mountain Plovers. Condor 84:71-74.

$\rightarrow$ LinK, W. A., AND J. D. Nichols. 1994. On the importance of sampling variance to investigations of temporal variation in anima population size. Oikos 69:539-544.

$\rightarrow$ Marsh, H., AND D. F. Sinclair. 1989. Correcting for visibility bias in strip transect aerial surveys of aquatic fauna. Journal of Wild life Management 53:1017-1024.

$\rightarrow$ Milchunas, D. G., And W. K. Lauenroth. 1993. Quantitative effects of grazing on vegetation and soils over a global range o $\rightarrow$ Theobald, D. M., D. L. STEVEns, JR., D. White, N. S. URQUhART, environments. Ecological Monographs 63:327-366.

$\rightarrow$ Milchunas, D. G., W. K. Lauenroth, P. L. Chapman, and M. K. KAzEMPOUR. 1990. Community attributes along a perturbation gradient in a shortgrass steppe. Journal of Vegetation Science 1:375-384.

$\rightarrow$ Miller, B., G. Ceballos, And R. Reading. 1994. The prairie dog and biotic diversity. Conservation Biology 8:677-681.

$\rightarrow$ Nichols, J. D., J. E. Hines, J. R. SAuer, F. W. Fallon, J. E. Fallon, AND P. J. Heglund. 2000. A double-observer approach for estimating detection probability and abundance from point counts $\rightarrow$ Auk 117:393-408.

$\rightarrow$ Orth, P. B., And P. L. Kennedy. 2001. Do land-use patterns influence nest-site selection by Burrowing Owls (Athene cunicularia hypugaea) in northeastern Colorado? Canadian Journal of Zoology 79:1038-1045.

$\rightarrow$ Plumb, R. E., F. L. Knopf, And S. H. Anderson. 2005. Minimun population size of Mountain Plovers breeding in Wyoming. Wilson Bulletin 117:15-22.

Samson, F. B., And F. L. Knopf, Eds. 1996. Prairie Conservation: Preserving North America's Most Endangered Ecosystem. Islanc Press, Washington, D.C.

$\rightarrow$ Samson, F. B., F. L. Knopf, And W. R. Ostlie. 2004. Great Plains ecosystems: Past, present, and future. Wildlife Society Bulletin 32:6-15. HuenNeKe, W. M. JarRell, R. A. Virginia, and W. G. WhitFORD. 1990. Biological feedbacks in global desertification. Science 247:1043-1048.

SMith, G. A., AND M. V. Lomolino. 2004. Black-tailed prairie dogs and the structure of avian communities on the shortgrass plains. Oecologia 138:592-602.

Stevens, D. L., JR., And A. R. Olsen. 2004. Spatially balanced sampling of natural resources. Journal of the American Statistical Association 99:262-278.

A. R. Olsen, And J. B. Norman. 2007. Using GIS to generate spatially balanced random survey designs for natural resource applications. Environmental Management 40:134-146.

Tipton, H. C. 2007. Occupancy, abundance, and density of Colorado breeding grassland birds: Estimation and habitat correlations. M.S. thesis, Colorado State University, Fort Collins.

VerCauteren, T. L., S. W. Gillihan, and S. W. Hutchings. 2001. Distribution of Burrowing Owls on public and private lands in Colorado. Journal of Raptor Research 35:357-361.

White, G. C., AND K. P. Burnham. 1999. Program MARK: Survival estimation from populations of marked animals. Bird Study 46 (Supplement):S120-S138.

Williams, B. K., J. D. Nichols, AND M. J. Conroy. 2002. Analysis and Management of Vertebrate Populations. Academic Press, San Diego, California.

$\rightarrow$ Winter, S. L., J. F. Cully, JR., And J. S. Pontius. 2003. Breeding season avifauna of prairie dog colonies and non-colonized areas in shortgrass prairie. Transactions of the Kansas Academy of Science 106:129-138.

Wunder, M. B., F. L. Knopf, And C. A. Pague. 2003. The highelevation population of Mountain Plovers in Colorado. Condor 105:654-662.

Associate Editor: D. H. Johnson 